\title{
Different responses of rat endometrial epithelium and stroma to induction of oestradiol binding sites by progesterone
}

\author{
Dominique Martel and A. Psychoyos \\ Laboratoire de Physiologie de la Reproduction, CNRS, E.R.203, Hôpital de Bicêtre, \\ 78 Av. du Général Leclerc, 94270, Bicêtre, France
}

\begin{abstract}
Summary. Rats were ovariectomized for 3 weeks and then treated for 3 days with 4 mg progesterone. The cytosolic oestradiol receptor content in the stroma cells was very high $(\sim 21000$ binding sites/cell) as compared with that in the epithelial cells ( $\sim 3000$ binding sites/cell). The nuclear receptor values were low ( $\sim 500$ binding sites/cell) in both types of cell.
\end{abstract}

\section{Introduction}

Experiments carried out mainly with immature rat uteri led to the concept according to which oestradiol induces the synthesis of its own receptor (Gorski, Sarff \& Clark, 1971), and progesterone antagonizes this effect (Hsueh, Peck \& Clark, 1976; Pavlik \& Coulson, 1976). However, although progesterone will often antagonize oestradiol, it can sometimes favour oestradiol action. For example, in the rat, oestradiol induces embryo implantation only after a progesterone priming of at least 2 days (Psychoyos, 1961, 1973). Earlier investigations of the progesterone-oestradiol interactions during the endometrial preparation for implantation (Mester, Martel, Psychoyos \& Baulieu, 1974; Martel \& Psychoyos, 1978) showed that the hormonal regulation of the oestradiol receptor levels in the rat uterus is more complex than initially supposed in that progesterone exhibits a double control on the oestradiol receptor production. First, it antagonizes the oestradiol-induced rise in oestradiol receptor level in the myometrium of ovariectomized rats and, second, it induces an increase in the oestradiol receptor concentration in the endometrium (Martel \& Psychoyos, 1978). In the present study, we have investigated the distribution of the oestradiol receptor between the luminal epithelium and the stroma of the endometrium in progesterone-primed ovariectomized rats.

\section{Materials and Methods}

Rats of the Wistar strain (4 months old) were ovariectomized and 3 weeks later were injected daily for 3 days with $4 \mathrm{mg}$ progesterone. At $24 \mathrm{~h}$ after the last injection, the uteri were removed and the epithelium was obtained according to the procedure of Casimiri, Rath \& Psychoyos (1977). This procedure left the stroma cells intact and these were then collected by gentle scraping. The control rats were not injected and the total endometrial tissue was separated from the myometrium as described previously (Martel \& Psychoyos, 1978). The tissues were placed at $0^{\circ} \mathrm{C}$ and all the following operations were carried out at $0^{\circ} \mathrm{C}$ unless otherwise specified. Subcellular fractions were prepared as previously described (Martel \& Psychoyos, 1976). The endometrium of 2 rats or the epithelium or stroma of 6 rats were homogenized in $1 \mathrm{ml}$ buffer (10 
mM-Tris- $\mathrm{HCl}, \mathrm{pH} 7.4,250 \mathrm{~mm}$-sucrose, $3 \mathrm{mM}-\mathrm{MgCl}_{2}$ ), filtered through gauze and centrifuged at $700 \mathrm{~g}$ for $10 \mathrm{~min}$. Cytosolic and nuclear oestradiol receptor levels were estimated as follows. Portions of cytosol were incubated in duplicate at $25^{\circ} \mathrm{C}$, in the presence of $10^{-8} \mathrm{M}\left[{ }^{3} \mathrm{H}\right]-$ oestradiol-17 $\beta$. The exchange of endogenous hormone (if present) with radioactive one is achieved ater a 24-h incubation (Katzenellenbogen, Johnson \& Carlson, 1973). At the end of incubation, free steroids were removed by the addition of $0.5 \mathrm{ml}$ of a charcoal suspension $\left(0.25 \%\right.$ Norit A, $0.025 \%$ Destran T-70 in buffer) and subsequent incubation for 5 min at $0^{\circ} \mathrm{C}$; the charcoal was then pelleted by centrifugation for $5 \mathrm{~min}$ at $700 \mathrm{~g}$. The $5 \mathrm{~min}$ charcoal treatment was repeated on the supernatant, using $50 \mu \mathrm{l}$ of a 10 -fold concentrated charcoal suspension; this second charcoal step was necessary because the background activity remained high after the first charcoal extraction due to the high content of hormone used in the assay. The non-specific binding was estimated from a parallel incubation carried out as above but in which a 100 -fold excess of unlabelled oestradiol had been added.

The $700 \mathrm{~g}$ crude pellets of nuclear material were washed in a $0.5 \%$ Triton X-100 solution in buffer and washed twice in an excess $(2 \mathrm{ml})$ of buffer. The pellets were incubated with $10^{-8}$ $\mathrm{M}-{ }^{3} \mathrm{H}$ loestradiol- $17 \beta$ in the presence (non-specific binding) or absence (total binding) of $10^{-6}$ M-oestradiol-17 $\beta$. The receptor labelling was achieved after $45 \mathrm{~min}$ of incubation at $37^{\circ} \mathrm{C}$ (Anderson, Clark \& Peck, 1972). At the end of the incubation, the nuclei were washed twice in buffer and submitted to an acid hydrolysis by incubation for $30 \mathrm{~min}$ at $70^{\circ} \mathrm{C}$ in $0.5 \mathrm{~N}-\mathrm{HClO}_{4}$. One half of the hydrolysate was used for counting radioactivity, the other for DNA determination (Burton, 1956). In each fraction the specific binding was obtained by subtracting the non-specific binding from the total binding. The results are expressed as oestradiol binding sites per cell, on the basis of 6.5 pg DNA per cell (Williams \& Gorski, 1972).

\section{Results}

As shown in Table 1, oestradiol receptor concentration was very low in the total endometrium of the control rats. The epithelial values for the progesterone-primed animals were similar to those of the controls. Nuclear receptor values in the stromal tissue were also low but receptor numbers in the cytosolic material were much increased.

Table 1. Oestradiol receptor concentrations in rat uteri

\begin{tabular}{ccccccc}
\hline \multicolumn{2}{c}{$\begin{array}{c}\text { Control } \\
\text { (total endometrium) }\end{array}$} & & \multicolumn{4}{c}{ Progesterone-treated } \\
\cline { 4 - 7 } \cline { 4 - 7 } & & & Stroma & \multicolumn{2}{c}{ Epithelium } \\
\hline Cytosol & Nucleus & & Cytosol & Nucleus & Cytosol & Nucleus \\
\hline $3640 \pm 1798$ & $622 \pm 149$ & & $20833 \pm 3890$ & $354 \pm 160$ & $2995 \pm 1815$ & $948 \pm 573$ \\
\hline
\end{tabular}

Values are mean \pm s.d. for 18 observations.

\section{Discussion}

We have demonstrated previously (Mester et al., 1974; Martel \& Psychoyos, 1978) that daily treatment of ovariectomized rats with progesterone results, after 2 days, in an increase of the cytosolic oestradiol receptor concentration in the endometrium. The present data show that this increase takes place in the stromal component of the endometrium. We further demonstrate that progesterone is not acting through its transformation to oestradiol, since the oestradiol formed would have induced the translocation of the receptor to the nucleus, and our data give no indication of increased nuclear receptor values.

Since the method we used to separate the endometrial tissues is possible only in rats that have been treated with progesterone, we were unable to obtain the epithelium and stroma separately in the control animals. We cannot therefore assess the initial content of oestradiol 
receptor in the stroma or epithelium. However, the cytosolic receptor concentrations for total endometrium in the controls was about the same (3000 oestradiol binding sites/cell) as that found in the epithelium of the progesterone-treated rats. It appears reasonable to suggest that the increased receptor values in the endometrium induced by progesterone is essentially related to the stromal component. Glasser \& McCormack (1979) have shown that the oestradiol receptor (cytoplasmic and nuclear) decreases in the epithelium but increases in the stroma cell during the first days of pregnancy in the rat, i.e. in a progesterone-dominated endometrium. The fact that progesterone increases the amount of oestradiol binding sites in the stroma may explain why priming by this hormone enhances the responsiveness of the stroma cells towards oestradiol (Martin \& Finn, 1968, 1969; Tachi, Tachi \& Lindner, 1972). The observations indicating the necessity of a progesterone priming for a response of stroma cells to oestradiol stimulation are numerous. For example, in the rat and mouse, a progesterone treatment lasting for at least 2 days is required to redirect the mitogenic action of oestradiol from the epithelium to the stroma (Martin \& Finn, 1968, 1969; Tachi et al., 1972). This delay may reflect the lag time necessary to achieve an optimal concentration of oestradiol receptor in the stromal cells.

Our previous observations (Martel \& Psychoyos, 1978) had shown that the endometrium and myometrium exhibit different responses to ovarian hormones. The present results indicate that the endometrium cannot itself be considered as an entity since the oestradiol receptor content of its two main cell populations differs after progesterone treatment.

This work was supported by the Centre National de la Recherche Scientifique, the Delégation Générale à la Recherche Scientifique and the Ford Foundation. We thank Marie-Noelle Monier for excellent technical assistance.

\section{References}

Anderson, J., Clark, J.H. \& Peck, J.H., Jr (1972) Oestrogen and nuclear binding sites. Biochem.J. 126, $561-567$.

Burton, K. (1956) A study of the conditions and mechanism of the diphenylamine reaction for the colorimetric estimations of deoxyribonucleic acid. Biochem. J. 62, 315-322.

Casimiri, V., Rath, N.C. \& Psychoyos, A. (1977) A simple method for separation and culture of rat uterine epithelial cells. J. Endocr. 73, 537-538.

Glasser, S.R. \& McCormack, S.A. (1979) Functional development of rat trophoblast and decidual cells during establishment of the hemochorial placenta. Adv. Biosci. 25, 165-197.

Gorski, J., Sarff, M. \& Clark, J.H. (1971) The regulation of uterine concentration of estrogen binding protein. Adv. Biosci. 7, 5-15.

Hsueh, A.J.W., Peck, E.J., Jr \& Clark, J.H. (1976) Control of uterine estrogen receptor levels by progesterone. Endocrinology 98, 438-444.

Katzenellenbogen, J.A., Johnson, J.H. \& Carlson, K.E. (1973) Studies on the uterine cytoplasmic oestrogen binding protein, thermal stability and ligand dissociation rate. An assay of empty and filled sites by exchange. Biochemistry, N.Y. 12, 4092-4099.

Martel, D. \& Psychoyos, A. (1976) Endometrial content of nuclear oestrogen receptor and receptivity for ovo-implantation in the rat. Endocrinology 99, 470-475.

Martel, D. \& Psychoyos, A. (1978) Progesteroneinduced oestrogen receptors in the rat uterus. $J$. Endocr. 76, 145-154.
Martin, L. \& Finn, C.A. (1968) Hormonal regulation of cell division in epithelial and connective tissues of the mouse uterus. J. Endocr. 41, 363-371.

Martin, L. \& Finn, C.A. (1969) Duration of progesterone treatment required for a stromal response to oestradiol-17 $\beta$ in the uterus of the mouse. $J$. Endocr. 44, 279-280.

Mester, J., Martel, D., Psychoyos, A. \& Baulieu, E.E. (1974) Hormonal control of oestrogen receptor in uterus and receptivity for ovo-implantation in the rat. Nature, Lond. 250, 776-778.

Pavlik, E.J. \& Coulson, P.B. (1976) Modulation of oestrogen receptors in four different target tissues: differential effects of oestrogen versus progesterone. J. Steroid Biochem. 7, 369-376.

Psychoyos, A. (1961) Nouvelles recherches sur l'ovoimplantation. C. r. hebd. Séanc. Acad. Sci. Paris D 252, 2306-2307.

Psychoyos, A. (1973) Hormonal control of ovoimplantation. Vitams Horm. 31, 201-255.

Tachi, G., Tachi, S. \& Lindner, H.R. (1972) Modification by progesterone of oestradiol-induced cell proliferation RNA synthesis and oestradiol distribution in the rat uterus. J. Reprod. Fert. 31, 59-76.

Williams, D.L. \& Gorski, J. (1972) Association behaviour of the oestradiol binding protein complex with the nuclear fraction. Acta endocr., Copenh. Suppl. 168, 420-452. 